\title{
Annual General Meeting of MRS-I Included Theme Seminar on Energy-Related Materials
}

The Eighth Annual General Meeting of the Materials Research Society of India (MRS-I) was jointly organized by Bhabha Atomic Research Centre (BARC) and MRS-I Bombay Chapter at Central Complex Auditorium, BARC during February 10-12, 1997. The meeting held a theme seminar on "Energy-Related Materials." About 330 delegates from different parts of India participated in this event.

In his inaugural address given on February 10, R. Chidambaram (Chair, Atomic Energy Commission) highlighted the current trends in materials research with a focus on processing of materials. In the context of the theme seminar of the meeting, he said that energy and materials have a symbiotic relationship. The production of energy depends on the availability of suitable materials and energy has to be expended for the production of materials. He elaborated on the interdependence of the two in the context of nuclear science and nuclear materials. He briefly mentioned significant achievements, including the completion of 40 successful years of operation of the APSARA reactor, the starting of the KAMINI reactor in Kalpakkam which marked the beginning of thorium utilization in the country, completion of 25 years of the Nuclear Fuel Complex, and the attainment of very high efficiency of the utilization of nuclear power reactors.

C.N.R. Rao (Founder President, MRS-I, and President, Jawharlal Nehru Centre for Advanced Scientific Research, Bangalore) commented on the growth of the interdisciplinary Materials Research Society of India. He emphasized the need for starting a dialogue between industries and the researchers in the forum. This will be of immense value in the current globalization of India's economy. To make India's industries competitive, he said, advanced materials research centers in the country would be essential to support indigenous industries in a spectrum of fields.

Anil Kakodkar (Director, BARC) briefly described the multifaceted materialsrelated research and development (R\&D) work in BARC. S.K. Joshi (President, MRS-I) referred to current topics such as materials for hydrogen and fusion energy, optoelectronic materials, conducting polymers, biomaterials, biomimetic materials, and intelligent materials. C.R. Gupta (Chair, MRS-I, Bombay Chapter) mentioned the emphasis placed on the poster presentations in which results of the latest

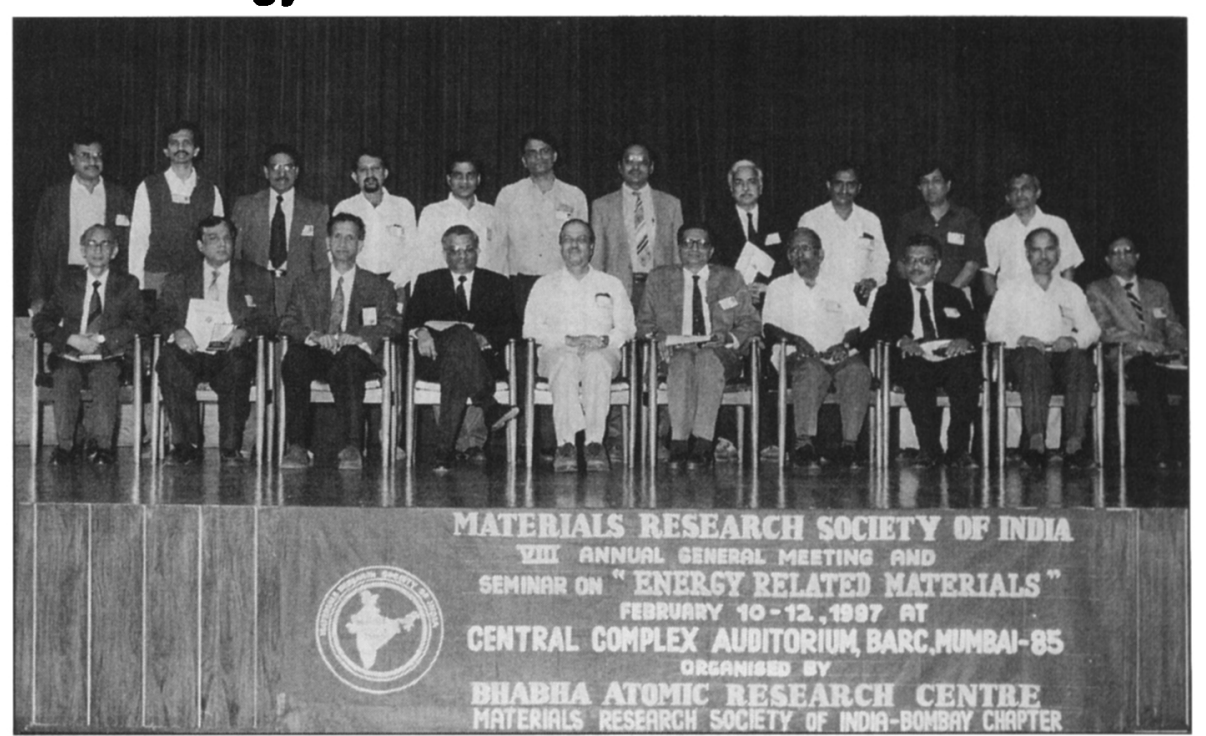

1997 MRS-I Medal recipients and the President of MRS-I

(Sitting, left to right) G. Banerjee, R. Jha, Paul Ratnasamy, Anil Kakodkar, S.K. Joshi (President of MRS-I), A.K. Barua, V.N. Krishnamurthy, N.G. Nair, R. Pinto, and A.C. Rastogi

(Standing, right to left) B.M. Mandal, V.D. Vankar, M.K. Surappa, B.P. Sharma, K. Bhanu Sankara Rao, M.C. Pandey, B.K. Godwal, A. Jayakrishnan, S.B. Krupanidhi, K.S. Narayan, and D. Bahadur

research have been reported.

In the three-day meeting, eight technical sessions were arranged. Highlights include the MRS-I honor lecture, two MRS-I Superconductivity and Materials Science Prize lectures, 18 MRS-I Medal lectures, eight invited lectures to cover the topics of the theme seminar, and a session devoted to a discussion on posters (125 posters were displayed).

Kakodkar received MRS-I Superconductivity Materials Science Prize. $\mathrm{He}$ delivered a lecture on "Materials Development for Emerging Nuclear Techniques." A.K. Barua (Indian Association for Cultivation of Science, Calcutta) was the second recipient of the same prize. Barua delivered a talk on "Materials Aspects of High-Efficiency Multifunction Amorphous Silicon Solar Cells." Apart from the lectures delivered by 18 recipients of MRS-I Medals, the MRS-I Honor Lecture was delivered by Paul Ratnasamy (Director, National Chemical Laboratory, Pune) on "Zeozymes, Novel Catalytic Material." An evening lecture on the second day of the meeting was delivered by $W$. Jeitsehke (University of Muenster, Germany) on "Ternary Alkaline Earth Lanthanide and Actinide Transition Metal Carbides."

The theme seminar was conducted on
February 11, addressing materials issues related to both conventional and nonconventional energy systems with an emphasis on nuclear fuel cycle and structural materials for nuclear reactors: "Materials Problems Connected with Thermal Power Stations" by Shri S. Balakrishnan (Manager, Tata Consulting Engineers, Bangalore); "Structural Materials for Nuclear Reactors" by D.D. Bhawalkar (Director, Centre for Advanced Technology, Indore); "Materials Issues in Nuclear Fuel Cycle" by Shri D.S.C. Purushottam (Associate Director, Nuclear Fuels, Automation and Manufacturing Group and Head, RadioMetallurgy Division, Bhabha Atomic Research Centre, Mumbai*); "Problems of Ash in Thermal Power Stations" by T.C. Rao (Director, Regional Research Laboratory, Bhopal); "Materials Issues in Fossil Fuel Powered Stations" by Shri S.A. Reddi, Dy. (Managing Director, Gammon India, Mumbai); "Materials Issues in Nonconventional Energy Production-Hydrogen-Based Energy Systems" by O.N. Srivastava (BHU, Varanasi); "Materials for Fusion Technology" by D. Chenna Reddy (Institute of Plasma Research, Ahmedabad).

\footnotetext{
* "Mumbai" was formerly called "Bombay.
} 


\section{MRS-I Medal Lectures 1997}

"Importance of Structural Tuning in Manganites," D. Bahadur, Indian Institute of Technology, Mumbai.

"Beach Sand Minerals: A New Material Resource for Glass and Ceramics," G. Banerjee, Central Glass and Ceramic Research Institute, Calcutta.

"On the Achievement of High Fatigue Resistance in Intermetallics," K. Bhanu Sankara Rao, Indira Gandhi Centre for Atomic Research, Kalpakkam.

"Electronic Topological Transition in Elemental Solids and Compounds," B.K. Godwal, High Pressure Physics Division, BARC, Mumbai.

"Therapeutic Opportunities using Polymeric Microspheres in Medicine and Surgery," A. Jayakrishnan, Sri Chitra Tirunal Institute of Medical Science and Technology, Trivandrum.

"Diffusion Path and Structure in Chromized and Aluminized Steels Based on $\mathrm{Fe}-\mathrm{Si}-\mathrm{Cr}, \mathrm{Fe}-\mathrm{Ni}-\mathrm{Cr}$, and $\mathrm{Fe}-\mathrm{Ni} \mathrm{Al}$ Systems," R. Jha, Tata Steel, Jamshedpur.

"Solid Propellants for ISRO's Missions," V.N. Krishnamurthy, Vikram Sarabhai Space Centre, Thiruvananthpuram.

"Ferroelectric Perovskite Thin Films in Current Microelectronics and Microelectromechanics," S.B. Krupanidhi, Material Research Centre, Indian Institute of Science (IISc), Bangalore.
"Conducting Polymer Nanocomposites with Extremely Low Percolation Threshold," B.M. Mandal, Indian Association for Cultivation of Science, Calcutta.

"Development of Composite Materials and Their Manufacturing Process," N.G. Nair, FRP Research Centre, Indian Institute of Technology, Madras.

"Photo-Induced and Electric Field Phenomenon in Semiconducting Polymeric Systems," K.S. Narayan, Jawaharlal Nehru Centre for Advanced Scientific Research, Bangalore.

"Development of an Iron-Based Alloy for the Substrate of Autocatalytic Converter," M.C. Pandey, Defence Metallurgical Research Laboratory, Hyderabad.

"High $\mathrm{T}_{c}$ Thin-Film SuperconductorsA Perspective," R. Pinto, Tata Institute of Fundamental Research, Mumbai.

"Tailormade Polymeric Materials with Predetermined Hydrophilic-Hydrophobic Balance: Design, Chemistry, and Applications," V.N. Rajasekharan Pillai, M.G. University, Kottayam.

"Nanostructured Semiconductor and Semimagnetic Thin-Film Materials for Optoelectronic Device Applications," A.C. Rastogi, National Physical Laboratory, New Delhi.

"Offshoots from Beryllium Development Programme," B.P. Sharma, Powder Metallurgy Division, BARC, Mumbai.

"Microstructure Evolution During Solidification of Aluminium Matrix
Composites" M.K. Surappa, Centre for Advanced Study, IISc, Bangalore.

"Chemical Vapour Deposited Diamond Thin Films," V.D. Vankar, Indian Institute of Technology, New Delhi.

\section{Best Posters}

The following four posters were chosen for the best poster awards and certificates:

"Tape Casting of Yitria Stabilized Zirconia as an Electrolyte for Application in Solid Oxide Fuel Cell," Amit Mukherjee, S.K. Pratihar, R.N. Basu, and H.S. Maiti, Electroceramics Division, Central Glass and Ceramic Research Institute, Calcutta.

"Preparation and Study of Sintered Ceramic Nanocomposite Glass," R.N. Viswanath and S. Ramaswamy, Department of Nuclear Physics, University of Madras, Guindy Campus, Madras.

"Synthesis and Microwave Absorption Studies of Ferrite-Based Paints," S.M Abbas, R.P.R.C. Aiyar (also of ACRE, Indian Institute of Technology, Powai, Mumbai) and Om Prakas, Department of Met. Engg. and Materials Science.

"Electron Cyclotron Resonance Plasma CVD-Grown Diamond and DiamondLike Carbon Thin Films," H.C. Barshitia, Somna Sah Mahyan, B.R. Mehta and V.D. Vankar Thin Film Laboratory, Department of Physics, Indian Institute of Technology, New Delhi.

P. RAMA RAO Past President MRS-I

\section{Are you planning a conference or short course? Promoting books or journals? Announcing your latest software?}

A mailing list from the Materials Research Society is exactly what you need!

Over 120,000 names of scientists and research managers who are active in forefront areas

of materials research and engineering. Lists are grouped in four main categories:

-Materials by application -Materials by properties -Materials characterization -Materials processing

MRS Mailing List Rental...

...reaching the broadest range of materials professionals directly!

Call today for more information or fax your order to Mary E. Kaufold

Materials Research Society, 506 Keystone Drive, Warrendale, PA 15086-7573

Telephone 412-779-8312; Fax 412-779-4397; E-mail Kaufold@mrs.org 